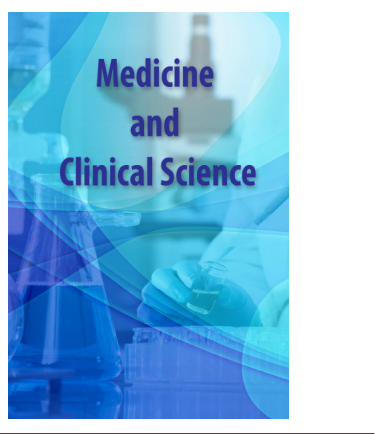

Correspondence

Dr. Noworol OV AM

ul. Okólna 4, skr. poczt. 10; 30-681 Kraków 47, Poland

E-mail: zagrozeniaduchowe@onet.pl

- Received Date: 10 Aug 2020;

- Accepted Date: 24 Aug 2020;

- Publication Date: 19 Sep 2020.

\section{Keywords:}

demonic healing; eye symptoms; iridology

Copyright

C) 2020 Science Excel. This is an open-

access article distributed under the terms of the Creative Commons Attribution 4.0 International license.

\title{
What is the value of iridology as a diagnostic tool?
}

\author{
Noworol OV AM \\ Pontifical University of John Paul II, Kraków, Poland
}

\begin{abstract}
The article discusses iridology. According to iridologists, the iris of the eye shows a disorder of the functioning of a given organ, or the state of health of different parts of the body, in the form of changes in the color of the iris, spots, shadows, etc., which occur on it. Nonetheless, ocular symptoms concerning the iris are relatively rare and can concern only a few diseases. However, the iris of the eye cannot be used to diagnose the general condition of the entire body, and on its basis it is not possible to read diseases or predispositions to them. The accuracy of iridology diagnosis is contradicted by clinical trials, and iridology is described as useless and potentially harmful. In the article iridology is discussed from the point of view of psychology, theology, and medicine, so as to answer the question whether and when this method can be a fraud, a spiritual threat or a method of treatment.
\end{abstract}

Iridology is a kind of so-called alternative, unconventional, holistic medicine. It is a controversial method, with many para-scientific assumptions, whose therapeutic practice stems from a specific world-view and religious system. Iridologists are said to diagnose the general condition of the whole organism on the basis of reading diseases, or predisposition to them, from the iris of the eye [1]. Many people seem to be able to do so because they desire health at all costs and in a somewhat simplified way, without God, conversion, work on themselves, the Church or faith [2]. However, neither diagnosis of diseases nor recovery is generally possible on the basis of iridology..

\section{What is iridology?}

Iridology is a form of diagnostics and unconventional treatment that is intended to diagnose the general state of health of the whole organism based on the reading of diseases, or predisposition to them, from the iris of the eye. Iridology assumes that all organs of the body are represented on the surface of the iris by nervous connections, and that the dysfunction of most organs is marked on the iris, usually as a pigmented lesion; the right half of the body is represented in the right iris, the left half in the left iris [1]. So the idea of iridologists is that the iris somehow reflects the health of different parts of the body.

Iridology has its roots in the East, Ancient Egypt and China; ancient doctors used iris appearance analysis to diagnose certain diseases $[3,4]$. However, the precursor of modern iridology was Hungarian physician Ignác Péczely. Péczely's iridology was based on his observation that in an owl, after a fracture of the paw, a noticeable black line appeared on the iris of the eye, which disappeared after the cure; and later he observed a similar line in a patient.

As a result of these observations, he divided the iris into 12 segments (similarly to astrologers who saw the fate of man in the eye, creating, among others, the zodiac of the eye), and assigned each part of the iris to a particular organ.

Also Nils Liljequist (one of the people who built the principles of iridology, which were later developed by, among others, M. Madaus, who started publishing the iridological journal "Iriscorrespondens" in 1920, and B. Jensen, author of the book The Science and Practice of Iridology, which is considered to be the basic textbook of iridology) has independently created similar iridological maps as Pécsely $[4,5]$.

Iridologists rely on iris maps. Iridological examination consists in a thorough examination of the iris (directly, with appropriate eye illumination, e.g. with a slit lamp, or they take high-quality colour photographs of both irises, sometimes supported by the analysis of specialized computer software). The image of the iris is then compared with iridological maps that assign specific locations on the iris to specific internal organs, i.e. they show a schematic division of the surface of the iris into fields that are supposedly the projection fields of particular internal systems and organs so that each part of the body has a corresponding place on the surface of the iris of the eye $[1,3,5]$. On an iris map, each iris is divided into 60 sectors (like a clock face), and each part is related to an internal organ or body function; e.g. heart diseases in the left iris between positions 2 and 3 hours [1].

Iridologists draw maps of the iris as if there is an anatomical or physiological mechanism (e.g. by the nervous system, the bloodstream) underlying the connection between the iris and the rest of the body; as if each internal organ and part of the body were represented in specific areas of the iris; as if the moles and discolourations of the iris reveal the condition of each organ, the inherited weaknesses and strengths, the inherited and acquired inclinations for health and disease; and as if the structure and colour of the iris inform about susceptibility to disease, about predisposition to specific diseases. Meanwhile, these iridological maps are one of the indicators of iridological baselessness, since none of them is able to accurately 
represent about 10,000 diseases (by mentioning the number from the ICD-10); moreover, there are different versions of the iridodiagnostic key, ways of analysing the iris, and iris maps, i.e. there is no single universal diagnostic key for the iris, and the same changes in the iris are interpreted differently by different iridologists $[1,3,4,5]$.

\section{Medically known eye symptoms}

According to iridologists, the iris of the eye shows abnormal functioning of a given organ in the form of changes in the colour of the iris, its spots, shadows, etc. Meanwhile, there are known medical ocular symptoms, occurring in systemic diseases; and some of them concern the iris. This, however, concerns very few of all known diseases, and does not give an univocal diagnosis. Namely:

- Non granulomatous anterior uveitis (acute and chronic), may indicate the following accompanying systemic diseases: ankylosing spondylitis (M45), Reiter's syndrome (reactive arthritis), Bahceta sickness, psoriatic arthritis, juvenile idiopathic arthritis, ulcerative colitis (K51), Leśniowski-Crohn's disease.

- Granulomatous anterior uveitis (one of the symptoms are iris nodules), may indicate the following accompanying systemic diseases: chronic sarcoidosis (D86), Vogt-Koyanagi syndrome, toxoplasmosis (B58), TB, syphilis, leprosy (A30); B-cell malignant lymphoma.

- Small, non-inflammatory, multifocal changes in the iris: Brushfield spots (symptoms: white or yellow spots, ring-shaped, located between the outer and middle parts of the iris), may be present in people with Down's syndrome (Q 90); The warts of the iris (symptoms: regular, thin, delicate, vermilion-like lesions) may be associated with the occurrence of Ota nevus, neuroblastoma (type 1), Rieger's syndrome; Lischa nodules (small, brown, domed nodules) may be associated with the occurrence of neuroblastoma (type 1).

- Vascular formation on the iris (new blood vessels on the iris), may indicate the following accompanying systemic diseases: diabetes mellitus; ischaemic ocular syndrome.

- Together with ocular-cutaneous albinism, transilumination of the iris may occur.

- In combination with Rieger's syndrome there may be posterior embryotoxone and malformations of the iris; hypoplasia of the essence of the proper iris (and pupil displacement, and apparent polycroticus); nipple-like elevations on the surface of the iris.

- Together with the Waardenburg syndrome, different colouring of the irises may occur.

- Together with diabetes, iris lesions with increased transilumination of the iris may occur.

- Down's syndrome can include iris hypoplasia, and Brushfield spotting.

- Leukemia may be accompanied by infiltration and thickening of the iris.

- In combination with neuroblastoma, type 1 (Recklinghausen's disease), there may be a congenital collapse of the iris pigmented epithelium.

- Including Ota's stigma, there may be nipple-like elevations on the surface of the iris.

- Together with ocular-cutaneous albinism (the tyrosine-negative form), the iris may be grey to blue with complete translucency.

- Together with ocular- cutaneous albinism (the tyrosine-positive form), the iris may be blue to yellow-brown with varying degrees of translucency.

- Including Sturge-Weber syndrome, there may be angioma of the iris and ciliary body on the same side.

- Combined with malignant cancer, there may be masses on the iris, which may be numerous.

- Kayser-Fleisher's ring may be associated with Wilson's disease (hepatocellular degeneration) [6].
So, few diseases can be diagnosed from the iris of the eye. Of course, there are also other diseases that give ocular symptoms (it happens that certain diseases give symptoms visible on the conjunctiva, cornea, sclera, lens, vitreous body, associated with changes in the bottom of the eye, orbit, optic nerve, eyeball muscles, tear gland and also on the eyelids), as well as eye diseases themselves [6]. However, iridology claims that it reads symptoms from the iris, so these correlations (which occur in some diseases but give symptoms in the form of changes noticeable in other parts of the eye) do not relate to the assumptions of iridology. But even if an iridologist consider the whole eye (there are iridologists who [although they diagnose from the iris by assumption] also look at other parts of the eyes; e.g. there are also references to sclera) [3], i.e. all its elements (as e.g. Jensen mentions some of the ocular symptoms concerning parts of the eye other than the iris) [7], not all diseases will be diagnosed on the basis of it, as many diseases do not give any ocular symptoms, and those that give may overlap in different diseases, making it impossible to make a clear diagnosis with iridiagnostics alone.

\section{Lack of accuracy of iridology diagnosis}

Lack of accuracy of iridology diagnosis also shows many studies. For example, studies have been carried out to determine whether iridology can detect susceptibility to cancer. The study was carried out on 110 people, 68 of whom had medically diagnosed breast, ovarian, uterine, prostate or colonic cancer, and 42 people were control subjects. All persons were examined by an experienced iridologist who did not know the medical details; he was allowed to suggest up to five diagnoses for each person, after which his results were compared with the medical diagnosis of each participant. The aim was to determine the accuracy of iridology, and to test the value of iridology as a diagnostic tool in the detection of certain cancers. The iridologist made a correct diagnosis in only 3 cases. These studies indicate that iridology is irrelevant in the diagnosis of the examined cancers [8].

Simon, Worthen, Mitas studied patients with kidney disease with creatinine concentrations higher than $106 \mu \mathrm{mol} / \mathrm{L}(1.2 \mathrm{mg} / \mathrm{dL})$; no kidney disease was present in the control group. Patients were evaluated as a total group, and as 2 subgroups, one with a moderately high concentration of creatinine (up to $433 \mu \mathrm{mol} / \mathrm{L}$ [ $4.9 \mathrm{mg} / \mathrm{dL}]$ ) and the other with a very high concentration of creatinine (557$1414 \mu \mathrm{mol} / \mathrm{L}$ [6.3-16.0 mg/dL]). Photographs of both irises of all 146 participants were taken, and 3 iridologists and 3 ophthalmologists were shown to categorize the images according to whether they concern patients with or without kidney disease. The frequency of true and false diagnoses did not differ significantly from accidental ones; therefore, none of the 6 observers received data of clinical importance [1,9].

Knipschild conducted research on 39 patients with cholecystitis (patients with jaundice were excluded). Gallbladder disease was chosen because many iridologists claim that it is impossible to overlook this disease. Stereo images of each patient's right iris were taken, and shown to the iridologists. Iridology proved to be an unusable diagnostic tool, as the accuracy, sensitivity, specificity, and consistency were not significantly different from random $[1,10]$.

Buchanan, Sutherland, Strettle, Terrell, Pewsey took color images of the irises of 4 groups of patients: ulcerative colitis $(n=30)$, coronary heart disease $(n=25)$, asthma $(n=30)$, and psoriasis $(n=30)$, and one control group. These images were analyzed both manually and with the help of a computer program, according to criteria generated by iridologists. In both types of analysis the results did not differ from random ones. Thus, it turned out that the diagnosis of these diseases could not be supported by iridological analysis $[1,11]$.

Thus, the results indicate that, under controlled conditions, iridologists cannot agree on the diagnosis, and are unable to distinguish between healthy and sick people. The benefits of iridology are not found, iridology does not bring results, does not provide useful information, its diagnosis is unreliable. Iridia diagnostics does not achieve any useful results for medical practice, and the claim that the early stages of various diseases (including cancer) can be diagnosed from the iris of the eye is unjustified [1]. 


\section{Iridology as a placebo effect}

Iridology, and its "reading from the eyes", can also be based on deception, suggestion, or placebo effect. In the case of healing there can be the so-called placebo effect, i.e. the patient heals, or his condition improves, only by hoping and suggesting that something will help him or her $[12,13]$.

Sometimes an iridologist can diagnose the general condition of the whole body based on the fact that while he is watching the iris, the patient will tell him about his health problems. Then the iridologist will "read" the disease (or a predisposition to it), but not from the iris of the eye, but from the information heard from the patient. An example of this are iridologists, who try to diagnose depression in this way, even though they are deprived of psychological-psychiatric competence; the diagnosis may turn out to be accurate, e.g. when the patient mentioned that he suffers greatly from grief (it is not known how often iridologists go so far as to "diagnose" mental disorders and diseases; nevertheless, such cases are known. For example, a person said that she went to an iridologist to help her recover because she felt generally sick; the iridologist looked her in the eyes, touched her head, and then asked if she had any problems, and when he heard that she had, said it was depression, and he prescribed antidepressants).

In addition, false healers, just like the mages-deceivers, use various tricks and they make themselves pay a lot for meaningless staging. Fraudsters usually use the opportunity to solve problems naturally (which happens in about half of the cases), e.g. by paying for a positive result; in effect, about half of the patients are coming back, and pay by thanking for nothing [14].

\section{Iridology as demonic healing}

Iridology, and its diagnosis has no scientific basis, this "reading from the eyes", or more precisely from the iris, is derived from Eastern belief systems. Iridology and its diagnosis may have a spiritual basis $[15,16]$. Spiritism is the calling of the dead or of the spirits to get answers to the questions posed to the spirits; however, spiritism deals with evoking evil spirits, and it is always that the evil spirits appear during spiritualistic sessions, even if they pretend to be the souls of dead, because the soul of the deceased cannot be evoked [14,17]. The only exception to evoke the deceased is in the Scriptures, when Saul turned to a fairy (medium), and instructed her to call the spirit of Samuel, which actually appeared. God allowed this exception, and you can see here the great surprise of the fairy (medium) and Samuel's reproach: Why don't you just leave me alone but you are evoking me? (1Sm 28,3-25; 1 Chr 10,13-14) [18]. Moreover, the inability of the souls of the dead to come to earth is evidenced by the parable of the rich man and Lazarus when the rich man wanted to go to his brothers, he heard a refusal: "If Moses and the Prophets do not listen, then no matter who comes from the dead, they won't believe" (Lk 16,19-31) [18]. God loves everyone, and if dialogue with the dead were good for people, God would recommend this form of contact; but He forbids it because He knows that such dialogue is bad for people. And although God may allow the dead to reveal themselves to people, the deceased cannot be summoned by men [14]. Thus, a method that uses spiritism, uses the help of evil spirits, and is also incompatible with the Catholic faith, since God condemns spiritism (Lv 20,27) [18].

Iridology and its diagnosis can have an occult background because the occult, esotericism, and esoteric occultism, in order to seize the secret powers, lead to magic and divination, are connected with the cult of the East, exteriorization, satanism, and many sects [14].

Many healers use the diagnosis of the eye, and the eye (iris) is for them a medium, i.e. the iris is like a contact bridge, used for telepathic or clairvoyant diagnosis. And such diagnosis is a form of spiritism, which in turn may give an accurate diagnosis, but a demonic diagnosis [19]. Thus, we are dealing here with a form of demonic healing [17,20]. An evil spirit can bestow physical health on someone, but then it causes destructive consequences for the human soul, psyche and even body. Demonic healing (to say it simply) consists in the healer summoning an evil spirit who can give someone physical health, but this healing is either only temporary, and then the person falls into an even more serious illness, or the person is physically healed, but loses faith $[17,20]$. So, an evil spirit can in some way give someone health, and this is possible in four classic ways.

- The first case is the transmission of symptoms. Someone had been suffering from a physical disorder for some time; the doctors could not help him; so he went to a healer who said that the person was under spell, which he declared to remove for a considerable amount of money. The person paid; and after a few days he felt completely cured. So temporarily, an evil spirit left this person. But after a year the same ailments, or a different and more serious illness, began to appear again; the person visited doctors again, the medication was ineffective, and the illness was getting worse and worse. It was the evil spirit that returned [17], with seven worse than himself (Mt 12,43-45) [18]. And this suffering person does not realize that it was the same sorcererhealer who contributed to the aggravation of his illness; so he returns to him. And this time the sorcerer tells her or him that she or he has been enchanted by a guesswork object with more power, and he can remove it for more money. The person agrees, and it starts all over again. If then this person eventually goes to an exorcist priest, then apart from a small initial illness, he or she must be freed from the great evil done by the sorcerer-healer. In this case, the person pays for his temporary health with a later more serious illness [17]. This is possible because evil spirits are the cause of illness and suffering for the soul and body ( $\mathrm{Jb} 2,7$; Lk 13,10-17) $[18,21]$, and various evils. Some diseases are caused by $\sin [22]$. And although suffering (physical, mental, spiritual) cannot be seen merely as a consequence of sins, it also cannot be completely separated from original sin and personal sins [23]. The influence of evil spirits is enormous; they are strong because they are spirits; they act in the world through hatred of God and men; however, their power is limited by God (Jb 1,6-12;2,16) [18]. God's providence guides history in a way that remains God's mystery [24].

- The second case: an illness transmitted to loved ones (the evil spirit is limited in its action by God, but has a greater effect on those who do not live in a state of sanctifying grace). The initial events repeat themselves as in the first case. The sick person pays, and is cured by a sorcerer. But suddenly it turns out that his wife, children, parents, etc. are sick, because his illness passes on to someone close to him. The evil spirit leaving one person only moves to make another person suffer worse. Here evil can be multiplied, also in the form of persistent atheism, sinful life, car accidents, various misfortunes, depression, etc. In this case, for his health, a man as if brought the disease on a loved one [17]. However, this does not happen as some have tried to justify the existence of generational sin; intergenerational sin does not exist (I.e., there is no sin carried from generation to generation, except the original sin; Ez 18,1-32) [18,25], and the disease so transmitted is also somehow related to the sin of the person to whom it passes.

- Third case: a disease transmitted to great spiritual damage. The initial events repeat themselves as in the first case. The sick person pays and is cured by a sorcerer. But suddenly he is no longer able to pray, stops going to church, loses faith, feels growing loathing and hate for all kinds of sacrum, etc. And here evil can be multiplied in the form of sinful life, atheism, various misfortunes, accidents, etc. In this case, man has paid for the health of the body with the health of the soul [17].

- Fourth case: body health, for the death of the soul. Initial events repeat themselves as in the first case. The person is cured by a sorcerer and this cure continues. In the case of this person the disease was allowed by God to atone for his sins, to return to a life of prayer, to go to church, and to enjoy the sacraments; the purpose of this disease was to obtain spiritual fruit for the salvation of his soul [17]. This can happen because many times in suffering, whether physical or mental, there is a special power 
that brings man closer to Christ inwardly, some special grace that leads to conversion, to inner maturity. In the sufferings permitted by God, there is at the same time a call from God's mercy; suffering is to serve conversion, repentance, overcoming the evil that dwells in man, and strengthening the good [23]. Through the healing of an evil spirit who knew God's intentions, the great spiritual fruits of that person's illness were lost [17]. In this case, the person was healed by an evil spirit, so that he remained immersed in sin and was not converted.

Thus, physical health may come from the devil, but evil spirits are not the cause of true healings, but the cause of diseases ( $\mathrm{Jb} 2,7 ; \mathrm{Lk}$ $13,10-17)[18,21]$ body, psyche, or soul, the diseases which sooner or later also appear after illusory healings. Occult gifts are the cause, the means of "healings" caused by evil spirits, and healers of all kinds, if they are not ordinary deceivers, are people gifted by evil spirits with various occult gifts. Not always you can see the evil immediately $[12,13]$, often it is only by the fruits that you recognize them $(\mathrm{Mt} 7,16)$ [18]. People usually value health, so they think that as good as it is, it can be gained in any way, but it is not. Health can be a devil's gift. An evil spirit acts in a deceptive and hidden way, seemingly healing (the overt action of evil spirits is to cause diseases of the soul and body, suffering (Jb 2,7; Lk 13,10-17) [18,21], and various evils [however, the overt activities of evil spirits are not the subject of this article]) and it works in a hidden way under the guise of goodness. In this way, various healing methods are based on the action of evil spirits, apart from iridology, such as bioenergotherapy (transferring to the sick person energy unknown to science, as it is not energy but demonic powers) [26,20], magnetism (one of the forms of healing by means of laying hands), white magic (a kind of magic seemingly connected with serving a human being, and allegedly used to help) [17,20], reiki (a method of healing by touch, and at a distance; among others through religious syncretism, in groups of Renewal in the Holy Spirit there appear people after the initiation of reiki, who e.g. want the Holy Spirit to improve the method of healing reiki in them) $[27,20]$, seemingly related to the service of man and used to "help" $[13,28,20]$. However, healing and magic is to resort to an evil spirit, and using the help of sorcerers can only help to increase the already existing evil [17], as in the Gospel, when an evil spirit came out of man to return to him with seven even worse evil spirits (Mt 12,43-45) [18].

\section{Iridology and other healing methods and a Christian approach to health and disease}

HUsing the services of healers can only contribute to the increase of already existing evil. Particularly important for Catholics is the fact that all practices by which one seeks to acquire secret powers to use them and achieve supernatural power over another person, even to ensure his health (including unconventional methods based on the power of evil spirits), are in serious contradiction with the virtue of religiousness. Whatever appearance of goodness, no excuse can be sought for calling out evil powers, nor for using the credibility of the other person [24]. Therefore, in case of illness, it is best to go to a doctor with a medical diploma, use medicines from a pharmacy, possibly herbal medicines, and pray. It is extremely important to pay attention to the spiritual aspects of human illness, seeking in them a means to atone for their sins, conversion, and other spiritual benefits. Soul health and salvation are most important. Besides, in troubles and sickness, even if prayer does not heal the body, it always helps the soul (Sir 38,1-15; Jas 5,14-15) [18,29]. God sometimes gives the gift of healing to his saints, but the praying one is not a healer, but an intermediary of God's gift of healing. The saints always emphasize that they pray and God heals; similarly, priests who pray for healing, they pray and God heals [30]. But the evil spirit acts in a deceptive and hidden way, seemingly healing.

It is interesting to note that iridology, although it has its own specificity and differs from other alternative methods, has much in common with them. For example, iridology and acupuncture (acupuncturists puncture selected places on the patient's body with needles, claiming that they cure, among others, by restoring energy balance (also other healing methods, like Chinese medicine, pilates, and other types of so-called alternative medicine, whose healing practice grows out of a specific world-view and religious system [incompatible with the Catholic faith], can sometimes be harmless, having nothing to do with occult practices, or can be combined with some forms of occult healing, or Eastern meditations, etc., being harmful then) are linked by holistic assumptions that one part of the body can connect with the rest of the body, systems, organs, etc., their health and sickness. Iridology is sometimes used in diagnostics by homeopaths. Homeopathic preparations are so diluted that almost always water alone is left; it is therefore water or water with sugar; if it heals so it is on the basis of the placebo effect; despite this often the method and production of homeopathic preparations are associated with magic, spiritism, the occult, or esotericism, and then there is the demonic healing $[20,31]$.

Healers according to themselves are "all-knowing" and think they have methods and cures for all diseases, problems and failures; they "take in" everyone, having "golden means" for everything. Their methods are seemingly connected with serving man, and are used to "help" $[13,28,20]$. However, they take advantage of credulity and naivety, and of the fact that their false good reputation attracts people seeking health at all costs, without paying attention to the consequences, as if life ends with death, as if they did not fully believe that earthly life is not everything, because there is eternity [32]. It is interesting to note that, like the "omni-knowledge" of iridologists healers, there are symbols of eyes that refer to omniknowledge. Such a symbol is the eye of Horus, which is a symbol of "protective", a symbol of power and omni-knowledge. Because the Eye of Horus was used in the old Egyptian art of healing, and energetic protection, therefore today some people attribute to this symbol the ability to protect against bad eyesight, preserve health, renew vitality, strengthen creative forces, mobilize for activity, help to know different points of view, and also the ability to protect against envy, jealousy, malice, and rejection of bad energy sent by other people. However, despite these appearances, in reality this symbol refers to Lucifer; the eye itself is half closed, to indicate that satan is still watching, although sometimes he does not seem to be doing so; below the eye you can see a tear, because satan weeps over those who are beyond his influence. Moreover, since in the past Horus' left eye was responsible for passivity and the past, the eye was painted on mummies and Egyptian tombs, and the symbol was supposed to be the eyes through which the soul of the deceased person watches the world and was believed to reincarnate through them; the symbol is also related to the supposedly existing reincarnation (in ancient Egypt the eye was a talisman put into a coffin to make the deceased's way in the hereafter easier) [33-37]. In turn, referring to the alleged existence of reincarnation, i.e. continuous dying and rebirth in a different form (there are many different concepts about the alleged existence of reincarnation) is the most common mistake of healers against the Christian faith. Eastern religions (Brahmanism, Jainism, among others), are a kind of source of faith in reincarnation [38] and healers of all kinds often refer to their faith in general reincarnation; for example, they tell people that the suffering they have suffered is karma (punishment or reward, a fate that cannot be changed). Meanwhile, reincarnation is simply an impossible hypothesis; reincarnation does not exist [14] because a man is given to die once and then a court (Heb 9,27) [18]. And the souls of the dead go to purgatory, heaven, or hell (this is the truth that has been confirmed by the Council of Lyon and Florence, among others) [14].

The symbolism of eyes is very rich (in general, eyes have many symbolic meanings and interpretations, e.g. already in ancient Egypt the eye was a talisman defending against evil, ensuring health, happiness, the rooster's eye was an amulet against magic, the newt's eye against disease and evil powers, etc.). In the past the left Eye of Horus was responsible for passivity and past, and the right eye was responsible for activity and future, together creating a symbol of omniscience. So the Eye of Horus is sometimes identified with the Eye of Ra, because in the heliopolitan system the god of Horus was identified (in the heliopolitan system the eye means life, and symbolizes the sun gods Ra [Re], Osiris, and Horus, who was 
originally worshipped as a falcon) with the sun god Re, and a new deity Re-Harachte was created; the sun became the Eye of Ra, and the moon became the Eye of Horus, who was joined together as a humanshaped god with the head of a falcon.

So the left Eye of Horus is clearly a symbol named Eye of Horus. This left eye, as the healing eye, was attributed with healing properties. Due to a complex historical trait, the right eye, the Eye of $\mathrm{Ra}$, some people identify with the other Eye of Horus (as a symbol of power it is sometimes identified with the healing Eye of Horus, or the wadjet's eye), but the right Eye of Ra is also called the symbol of udjat (the wadjet [wedjat]; the so-called all-seeing eye, the eye of Lucifer). Udjat was originally a hieroglyphic and Egyptian symbol, and this is the Eye of Ra [Re]; the right Eye of Ra, which meant the sun. The Eye of $\mathrm{Ra}$, as the right burning eye of $\mathrm{Ra}$, destroys enemies.

Udjat nowadays, pretend to symbolize the all-seeing eye (the allseeing "eye of the world" 'the sun' is also the Indian fire god Agni and Buddha), which, although slightly closed, reminds us that the devil is observing man; it is supposed to mean Lucifer's "care" for his followers, and provide "protection" for the satanists and the occultists. The tear that falls below is meant to mean Lucifer's "crying" over those who are beyond his influence. In occultism and satanism, it is a symbol referring to Lucifer, and satanists and occultists often use this symbol, or selected parts of it; they also use it as a tool to open themselves to the gift of clairvoyance (demonic gift). However, referring to the Egyptian "evil eye", the eye of Osiris, and the "devil's eye", which looks upon and is supposed to control society [33$35,37,39]$, in addition to symbols, many people attribute to human eyes the possibility of casting charms, which, however, are possible by the power of evil spirits and evil intentions, and not the properties of the eyes themselves [17]. Therefore, motivated by the kabbalah followers, the need to wear red thread on one's wrist to protect him or her from the so called "bad eye" (a bad eye is a bad look that casts a spell; it works through envy, and is the cause of misfortune, even death; a person with a bad eye carries a destructive, negative power), has no justification or protection; usually it creates the opposite, namely a symbolic seal of parareligious affiliation, a hidden demonic recall (that is why you cannot be a Catholic, and wear a red thread on your wrist) $[36,40,41]$. Similarly, an amulet to protect against the socalled evil eye is the Eye of Fatima (the Eye of the Prophet, the Nazar, the blue eye), originating in Turkey; it is an amulet made mostly of glass, in the form of a blue droplet or a shield with circles painted concentrically alternately white, light blue, and dark blue. And also an amulet to protect against the so-called bad eye, and bad energy, is Fatima's Hand (Miriam's hand); five fingers of the extended hand are to serve as a defence against the bad eye. Whereas only God protects against charms, so amulets and talismans do not give protection, but prayer to God (34-36].

Moreover, there are no exorcists using iridology. The real exorcists are exclusively Catholic Bishops, or Diocesan or monastic priests, who are authorized to perform a solemn exorcism [42]; only specific priests can perform a solemn exorcism (exorcism is a liturgical ritual performed to liberate a person, place or thing from the influence of an evil spirit; it is a kind of prayer to drive out evil spirits or to free a person or object [house, animal, thing, place, etc.] from the demonic influence; a demonic phenomenon may be associated with a house or object) $[17,43]$. There is a warning in Scripture not to believe in the possibility of a secular exorcist: Acts 19:11-16. Lay people who pretend to be "exorcists" are ordinary scammers who "exorcise" for money, and People acting in bad faith, whose actions boil down to hidden occultism and spiritism, and their false exorcisms are a source of serious threats to the soul and body. Exorcists, like all priests, are servants of the Most High God heralding the way of salvation (Heb 16,17) [18]; Exorcist priests receive power over evil spirits, just like the Apostles whom Jesus commanded to cast out evil spirits (Mk 6,7; Mt, 10,1.8; Mk 3,1415 ; Lk 9,1) [18]. And although some healings take place very slowly, exorcists save a lot of people, because the environment of exorcist priests is prayer and grace [14,17]. In addition, there are other prayers against evil spirits, among others, each person can pray for himself or herself to St. Michael the Archangel (St. Michael the Archangel, defend us in battle. Be our defense against the wickedness and snares of the Devil. May God rebuke him, we humbly pray, and do thou, O Prince of the heavenly hosts, by the power of God, thrust into hell satan, and all the evil spirits, who prowl about the world seeking the ruin of souls. Amen.) to pray and fast (there are evil spirits that can be cast out by prayer and fasting (Mk 9,14-29) [17,18]. Iridology is not reliable, and can sometimes cause medical and spiritual damage. Spiritual, because contact with healers who use spiritism, the occult, etc., is a danger to human faith $[17,20]$. Healers, when using demonic powers, cannot make their "healings" with people who pray with faith; e.g. they advise against keeping crosses on walls as sources of "bad energy", etc. This in turn is a testimony given about oneself that the method is not appropriate for Catholics if it draws from sources that are incompatible with prayer and faith. Medical, because it is possible to diagnose and recommend the treatment of diseases that do not exist; or to consider as a healthy person who is ill, and even more seriously ill person, because in such cases precious time to start treatment as soon as possible may be lost [1].

\section{Conclusion}

The analysis carried out shows that some of the iridologists, and the methods they use, may be harmless in themselves (then the main danger is to discourage conventional treatment for patients), and this pseudo-healing persists despite a lack of credibility and effectiveness because it can treat on a placebo basis. Patients may also feel better because of other parallel treatments, e.g. some iridologists recommend dietary supplements or herbs.

The second part of iridologists, and their methods, are diagnoses and treatment methods, which are "remote healing", i.e. varieties of demonic healing. The use of their services can only contribute to the enlargement of the already existing evil. In contrast to prayer, which is a rescue for the sick person, always helping the soul and usually the health of the body (Sir 38,1-15; Jas 5,14-15) [18].

The third part is those iridologists who are somehow based on the healing methods of medicine; these iridologists are able to see manifestations of very specific, rare diseases, but they are unable to diagnose most of the known diseases and illnesses.

\section{References}

1. Ernst, E. Iridology: not useful and potentially harmful. Archives of Ophthalmolgy. 2000;118(1):120-121.

2. Markielowski P. Bóg chce uzdrowić całą rodzinę. [God wants to heal the whole family.] Wywiad z Ks. Piotrem Markielowskim, egzorcystą diecezji kieleckiej - rozmawia Artur Winiarczyk. [An interview with Father Piotr Markielowski, an exorcist of the Kielce diocese - interviewed by Artur Winiarczyk.] Egzorcysta. 2013. 9(13):1219.

3. Szmukała-Rostovceva A. Irydologia zilustrowana. Praktyczny poradnik. Znaki irydologiczne na ponad 230 zdjęciach. [Illustrated iridology. A practical guide. Iridium signs in over 230 photos.] Gdańsk: Gdańskie Wydawnictwo Psychologiczne 2014.

4. Karpov S, Chmielewska W. Irydologia w praktyce. [Iridology in practice.] Gliwice: Złote Myśli 2008.

5. Jensen B, Bodeen DV. Co Twoje oczy mówią o zdrowiu. Irydologia $\mathrm{w}$ praktyce. [What your eyes say about health. Iridology in practice.] Białystok: Studio Astropsychologii 2011.

6. Kański J. Objawy oczne w chorobach układowych. Objawy i diagnostyka różnicowa. [Ocular symptoms in systemic diseases. Symptoms and differential diagnosis.] Wrocław: Górnicki Wydawnictwo Medyczne 2002.

7. Jensen B. Iridology Science and Practice in the Healing Arts. Volume II. Escondido, CA: Bernard Jensen, Publisher 1982.

8. Münstedt K, El-Safadi S, Brück F, Zygmunt M, Hackethal A, Tinneberg HR. Can iridology detect susceptibility to cancer? A prospective case-controlled study. Journal of Alternative and Complementary Medicine. 2005. Jun, 11(3):515-519.

9. Simon A, Worthen DM, Mitas JA. An evaluation of iridology. 
JAMA. 1979. 242:1385-1389.

10. Knipschild P. Looking for gallbladder disease in the patient's iris. BMJ. 1988. 297:1578-1581.

11. Buchanan TJ, Sutherland CJ, Strettle RJ, Terrell TJ, Pewsey A. An investigation of the relationship between anatomical features in the iris and systematic disease with reference to iridology. Complementary Therapies in Medicine. 1996. 4:98-102.

12. Jaworowski B. Zniewolenia duchowe. Mp3 (patronat: radio Emaus), dodatek do Przewodnika Katolickiego. [Spiritual enslavement. Mp3 (patronage: radio Emmaus), supplement to the Catholic Guide.] In: Przewodnik Katolicki 2012. 24.

13. Jaworowski B. Zagrożenia związane $\mathrm{z}$ okultyzmem, audycja Radia Maryja [The risks associated with the Occult, Radio Maryja's broadcast] 22.02.2008.

14. Amorth G. Egzorcyści i Psychiatrzy. [Exorcists and Psychiatrists.] Częstochowa: Edycja Świętego Pawła 1999.

15. Cyran Wł. Kroki do wolności od złych duchów. Przewodnik duchowy dla osób zniewolonych lub dręczonych. [Steps to freedom from evil spirits. A spiritual guide for those enslaved or tormented.] Częstochowa: Wyd. Wspólnota Przymierza Rodzin „MAMRE” 2013.

16. Zwoliński A. Mały leksykon zagrożeń duchowych. [A small lexicon of spiritual threats.] Częstochowa: Edycja Świętego Pawła 2011.

17. Amorth G. Wyznania egzorcysty. [Confessions of an exorcist.] Częstochowa: Edycja Świętego Pawła 2007.

18. Pismo Święte Starego i Nowego Testamentu. Wyd. 5, opracował zespół Biblistów Polskich. [Scripture of the Old and New Testament (2000). Edition 5, prepared by the team of Polish Biblilists.] Poznań: Pallottinum 2000. Corresponding Scripture in English: United States Conference of Catholic Bishops, Books of the Bible. https://bible.usccb.org/bible

19. Koch KE. Okkultes ABC. [Occult ABC.] Schwäbisch Gmünd: Ebner Ulm 1996.

20. Noworol OV AM. Jak rozpoznać złego ducha, i jak pomagać zniewolonym przez demony? [How to recognize the evil spirit, and how to help those enslaved by demons?] Kraków: Petrus 2018.

21. Léon - Dufour X, ed. Słownik Nowego Testamentu. [Dictionary of the New Testament.] Poznań: Pallottinum 1981.

22. Bashobora JB. Jesteś obrazem Boga. Treści konferencji wygłoszonych podczas rekolekcji w Polsce w roku 2011. [You are an image of God. Content of the conference delivered during the recollections in Poland in 2011.] Częstochowa: POMOC, Wyd. Misjonarzy Krwi Chrystusa 2012.

23. Jan Paweł II. List Apostolski Salvifici Doloris. [Apostolic Letter Salvifici Doloris.] Wrocław: Wyd. Wrocławskiej Księgarni Archidiecezjalnej 1984.

24. Katechizm Kościoła Katolickiego. [Catechism of the Catholic Church.] Poznań: Pallottinum 1994; no. 395, 2117.

25. Komisja Nauki Wiary Konferencji Episkopatu Polski, (Opinia teologiczna Komisji Nauki Wiary Konferencji Episkopatu Polski). Grzech pokoleniowy i uzdrowienie międzypokoleniowe. Problemy teologiczne i pastoralne. [Commission on the Science of Faith of the Polish Bishops' Conference, (Theological Opinion of the Commission on the Science of Faith of the Polish Bishops' Conference). Generational Sin and Intergenerational Healing. Theological and pastoral problems.] Warszawa 5.10.2015.

26. Tekieli R. Bioenergoterapia. Don Bosko. [Bioenergotherapy] http://www.katolik.pl/bioenergoterapia,2103, 416,cz.html?s=1.; http://www.katolik.pl/bioenergoterapia,2103,416,cz. html?s=2

27. Pindel R. Metoda leczenia czy sekta? [Treatment method or a sect?] http://www.psychomanipulacja.pl/art/metoda-leczeniaczy-sekta.htm

28. Jaworowski B, Krupa P. Czy okultyzm zagraża rodzinie?, audycja radia Maryja [Does the occult threaten the family?, Radio Maryja's broadcast] 15.04.2008.

29. Díaz Covarrubias E. Cierpliwość Boga, niecierpliwość człowieka. [God's patience, man's impatience.] Kraków: Petrus 2020.

30. Peroni L. Ojciec Pio. Pełna biografia w 40. rocznicę śmierci. t. I i II.[Padre Pio. Full biography on the 40th anniversary of his death. Vol. I and II.] Kraków: Rafael 2008.

31. Lisowski JP. Prawda o homeopatii. In: Homeopatia. Śmierć w granulkach? [The truth about homeopathy. [in:] Homeopathy. Death in pellets?] Warszawa: Monumen 2016; p.11-18.

32. Ratzinger J. Bóg Jezusa Chrystusa. Medytacje o Bogu Trójijedynym. [God of Jesus Christ. Meditations on the Triune God.] Kraków: Znak 1995.

33. Bacik G. Okultyzm. O zagrożeniach płynących z uwikłania w spirytyzm, magię i wróżby.[Occultism. About the dangers of being entangled in spiritism, magic and divination.] Kraków: Esprit 2009.

34. Lurker M. Przesłanie symboli w mitach, kulturach i religiach. [The message of symbols in myths, cultures and religions.] Warszawa: Aletheia 2011.

35. Zwoliński A. Ilustrowany leksykon symboli. [Illustrated lexicon of symbols.] Kraków: wyd. Wejdźmy na szczyt 2017.

36. Kopaliński W. Słownik symboli. [Dictionary of symbols.] Warszawa: Wydawnictwo Wiedza Powszechna 1990.

37. Niebezpieczne znaki dla twojej wiary, duchowości i tożsamości chrześcijańskiej! Plakat (za zezwoleniem władzy duchownej). [Dangerous signs for your faith, your spirituality and your Christian identity! Poster (with the permission of the clerical authority).

38. Krąpiec MA. Dlaczego zło? [Why the evil?] Lublin: Polskie Towarzystwo Tomasza z Akwinu 2005.

39. Keller J, Kotański W, Tyloch, W, Kupis B, ed. Zarys dziejów religii. [An Outline of Religious History.] Warszawa: Iskry 1988.

40. Czerwona nitka. [Red thread.] http://pl.kabbalah.com/content/ czerwona-nitka

41. Czerwona nitka nieszczęścia. [Red thread of unhappiness.] http://www.newage.info.pl/index.php?option=com_content\&ta sk=view\&id $=303 \&$ Itemid $=25$

42. Kodeks Prawa Kanonicznego.[Code of Canon Law.] Poznań: Pallottinum 1984; can.1168,1172.

43. Nowa Encyklopedia od A do Z. [New Encyclopedia from A to Z.] Warszawa: Świat Książki 2005; p.167. 